\title{
The Preparation of Foam Concrete with Iron Tailings
}

\author{
Jing $\mathrm{Xu}$, Shaowei $\mathrm{Yao}^{\mathrm{a}}$
}

Hebei Provincial Key Laboratory of Inorganic Nonmetallic Materials; College of Materials Science and Engineering, North China University of science and Technology; Tangshan 063009, China

ayaoshaowei389@163.com

Keywords: foam concrete; iron tailings; dry density; compressive strength

Abstract: In this paper, iron tailings and cement are used as the basic raw materials. Through studying strength and dry density, we explore the feasibility of preparation of foam concrete using iron tailings.

\section{Introduction}

With the number of new mine increasing, the amount of tailings' discharge and accumulation are bigger and bigger. Tailings' accumulation not only lead the land occupied, but also has a hidden trouble ${ }^{[1]}$. Iron tailings as a secondary energy is focused all over the world, so it becomes a promising direction to improve the utilization rate of resources ${ }^{[2]}$. The performance of foam concrete have small density, light quality, heat preservation, sound insulation, heat insulation, seismic performance and so on ${ }^{[3]}$. The performance and preparation of the foam concrete get people's more and more attention. Iron tailings will be used effectively if it can be used as the raw materials of foam concrete.

\section{Experiment}

Raw materials : cement (Jidong ordinary Portland cement); water: Tangshan city tap water; Foaming agent: foaming agent factory's HTW-1type of Zibo city in Shandong province. iron tailings : Qianan city iron plant, take a part of size $5 \mathrm{~mm}$, grind $40 \mathrm{~min}$ and $60 \mathrm{~min}$. The apparent density and specific surface area are shown in Table 1.

Experiment process: foaming agent is diluted 30,40,50 times firstly and then stirred to generate bubbles for using; At the same time, iron tailings powder, cement, fine aggregate and water are mixed in the blender, then we put the bubbles in the blender and mold specimens. Specimens are cured standardly, demoulding time of specimens is $48 \mathrm{~h}$. The specimen size is $100 \times 100 \times 100 \mathrm{~mm}$. The testing basis of strength is 《the test method's standard of odinary concrete's mechanics performance》(GB/T 50081-2002). Three specimens are baked to dry at $65 \pm 2^{\circ} \mathrm{C}$ and weighed when curing $3 \mathrm{~d}$.

Table 1 The density and specific surface area of iron tailings

\begin{tabular}{lcc}
\hline specimens & apparent density $\left[\mathrm{g} \cdot \mathrm{cm}^{-3}\right]$ & specific surface area $\left[\mathrm{m}^{2} \cdot \mathrm{kg}^{-1}\right]$ \\
\hline ball-milling 40 min & 2.83 & 360 \\
ball-milling 60 min & 2.85 & 480 \\
\hline
\end{tabular}

The grading of iron tailings is measured by laser particle size analyzer, as shown in Fig. 1, Fig. 2. 


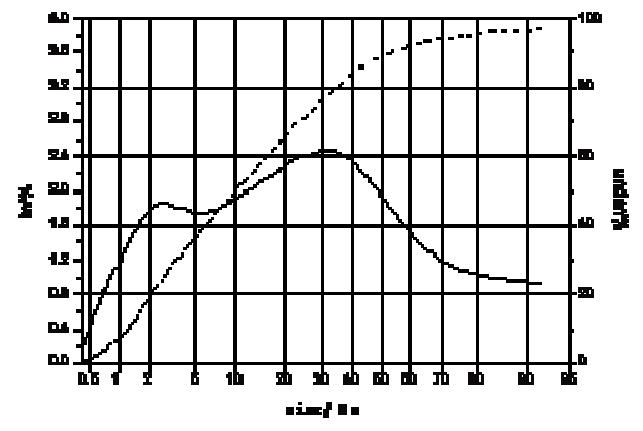

Fig. 1 Iron tailings I (40 min)

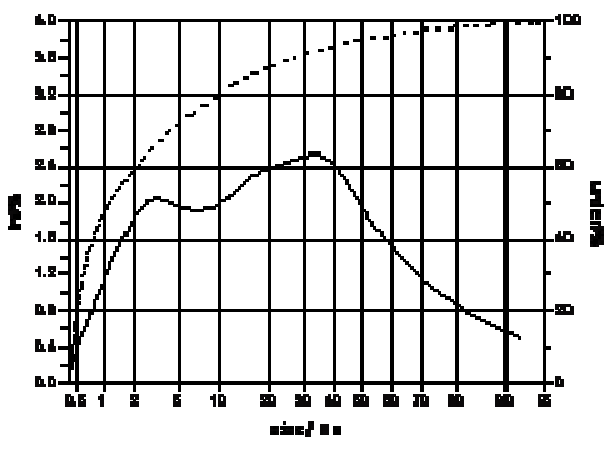

Fig. 2 Iron tailings II (60 min)

\section{The experimental results and conclusion}

The testing results of Foam concrete are shown in Table 2.

Table 2 Different ratio of foam concrete's compressive strength

\begin{tabular}{|c|c|c|c|c|c|c|c|c|c|c|}
\hline \multirow{2}{*}{ NO. } & \multirow{2}{*}{$\begin{array}{c}\text { Foaming } \\
\text { agent } \\
\text { times }\end{array}$} & \multirow{2}{*}{$\begin{array}{c}\text { Water } \\
{\left[\mathrm{kg} \cdot \mathrm{m}^{-3}\right]}\end{array}$} & \multirow{2}{*}{$\begin{array}{l}\text { Cement } \\
{\left[\mathrm{kg} \cdot \mathrm{m}^{-3}\right]}\end{array}$} & \multirow{2}{*}{$\begin{array}{c}\text { Iron } \\
\text { tailings } \\
{\left[\mathrm{kg} \cdot \mathrm{m}^{-3}\right]}\end{array}$} & \multirow{2}{*}{$\begin{array}{c}\text { Foaming } \\
\text { agent } \\
{\left[\mathrm{kg} \cdot \mathrm{m}^{-3}\right]}\end{array}$} & \multirow{2}{*}{$\begin{array}{c}\text { Foaming } \\
\text { agent } \\
\text { water } \\
{\left[\mathrm{kg} \cdot \mathrm{m}^{-3}\right]}\end{array}$} & \multicolumn{3}{|c|}{$\begin{array}{c}\text { compressive strength } \\
{[\mathrm{MPa}]}\end{array}$} & \multirow{2}{*}{$\begin{array}{c}\text { Dry } \\
\text { density } \\
{\left[\mathrm{kg} \cdot \mathrm{m}^{-3}\right]}\end{array}$} \\
\hline & & & & & & & $3 d$ & $7 d$ & $28 d$ & \\
\hline 1 & 30 & 190.0 & 475.0 & 0.0 & 0.5 & 15.0 & 1.52 & 1.89 & 2.65 & 580 \\
\hline 2 & 30 & 190.0 & 427.5 & 47.5 & 0.5 & 15.0 & 0.76 & 0.96 & 1.39 & 580 \\
\hline 3 & 30 & 190.0 & 332.5 & 142.5 & 0.5 & 15.0 & 0.89 & 1.11 & 1.69 & 650 \\
\hline 4 & 30 & 190.0 & 237.5 & 237.5 & 0.5 & 15.0 & 0.33 & 0.36 & 0.56 & 580 \\
\hline 5 & 40 & 190.0 & 475.0 & 0.0 & 0.5 & 20.0 & 1.49 & 1.81 & 2.61 & 600 \\
\hline 6 & 40 & 190.0 & 427.5 & 47.5 & 0.5 & 20.0 & 0.58 & 0.95 & 1.44 & 610 \\
\hline 7 & 40 & 190.0 & 332.5 & 142.5 & 0.5 & 20.0 & 0.74 & 0.98 & 1.38 & 660 \\
\hline 8 & 40 & 190.0 & 237.5 & 237.5 & 0.5 & 20.0 & 0.21 & 0.30 & 0.56 & 520 \\
\hline 9 & 50 & 190.0 & 475.0 & 0.0 & 0.5 & 25.0 & 1.37 & 1.66 & 2.49 & 580 \\
\hline 10 & 50 & 190.0 & 427.5 & 47.5 & 0.5 & 25.0 & 0.30 & 0.50 & 0.79 & 610 \\
\hline 11 & 50 & 190.0 & 332.5 & 142.5 & 0.5 & 25.0 & 0.65 & 0.83 & 1.19 & 590 \\
\hline 12 & 50 & 190.0 & 237.5 & 237.5 & 0.5 & 25.0 & 0.13 & 0.35 & 0.53 & 580 \\
\hline
\end{tabular}

According to the experimental data, at the same diluted times, the strength of foam concrete is highest which is made by pure cement; when diluted multiples of the foaming agent is 40 times ,the strength of corresponding foamed concrete is relative bigger; The amount of cement are replaced by iron tailings at $30 \%$, the strength of foamed concrete is highest. The reason: (1) foam concrete's low dry density and high porosity make foam concrete easy to produce stress concentration. (2) with the dilution ratio of foam agent increasing, the strength of foam concrete are reduced.(3) the gelling of iron tailings is poor, but iron tailings can play a role of micro aggregate, so the appropriate proportion of iron tailings contributes to the strength of foam concrete.

The part images of foam concrete (amplification 60 times) are shown in Fig. 3, Fig. 4, Fig. 5. 


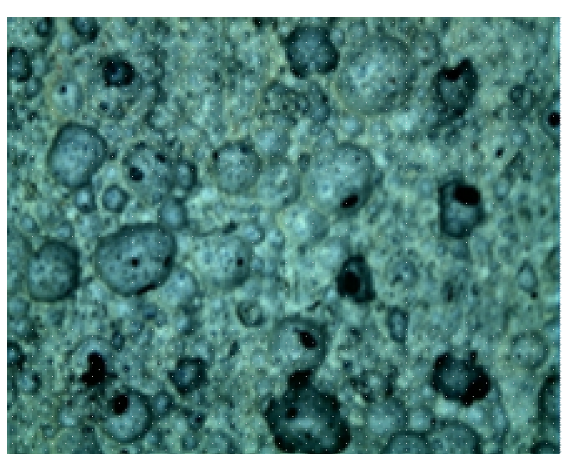

(a)

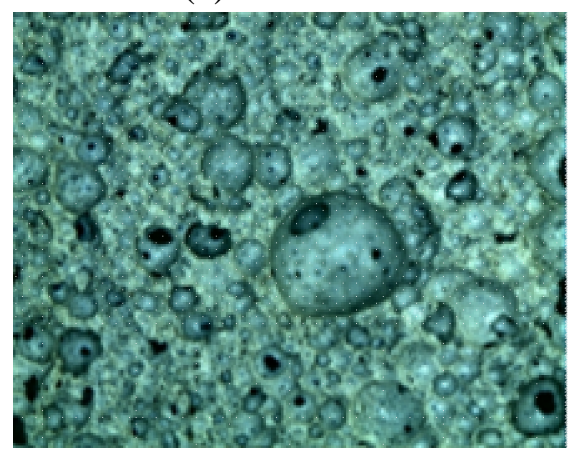

(c)

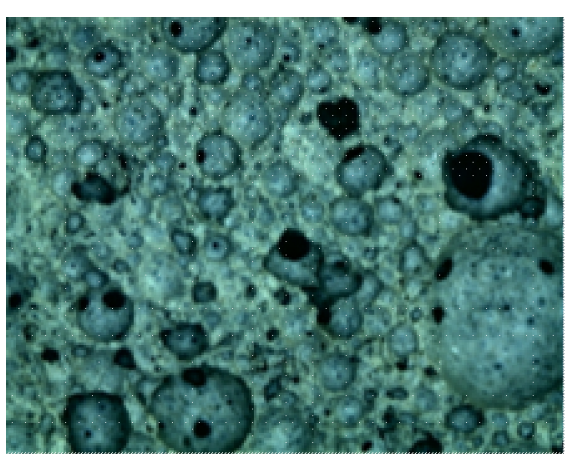

(b)

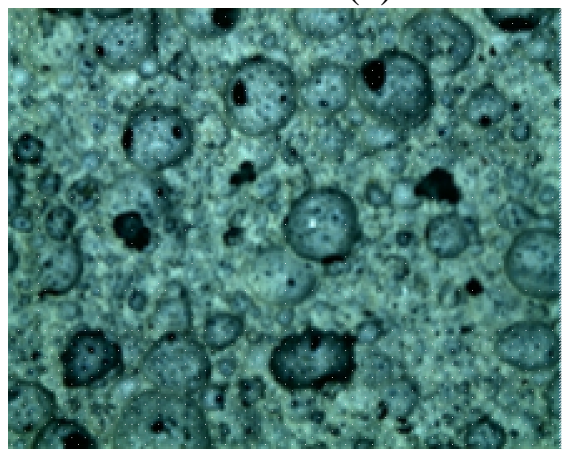

(d)

Fig. 3 When diluted multiples of the foaming agent is 30 times, the part images of foam concrete. The amount of cement are replaced by iron tailings at $0 \%$ (a), 10\%(b), 30\%(c) and 50\%(d) of the foam concrete.

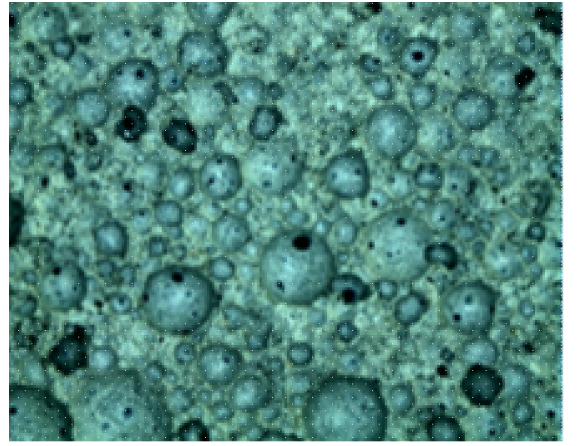

(a)

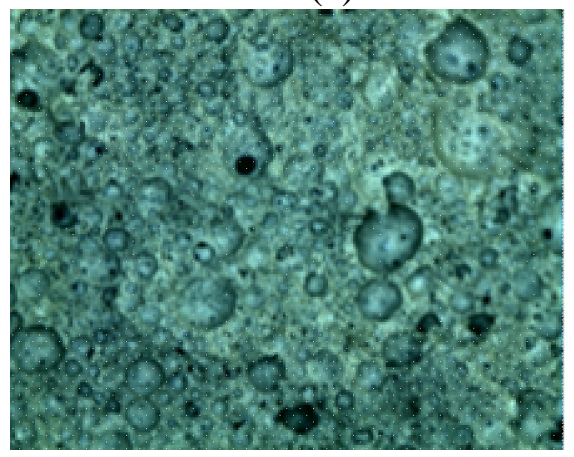

(c)

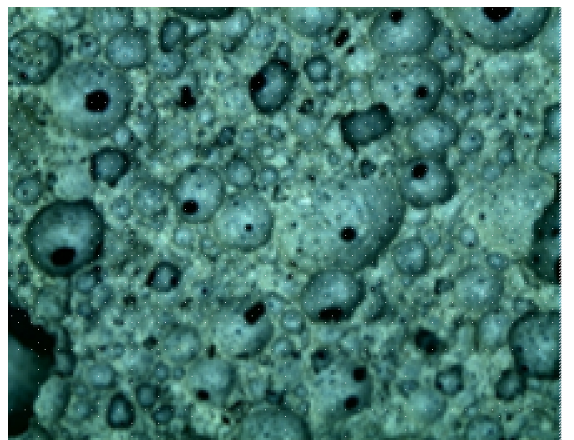

(b)

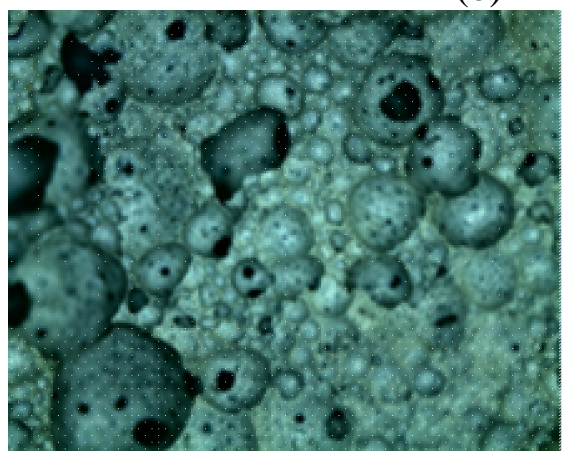

(d)

Fig. 4 When diluted multiples of the foaming agent is 40 times, the part images of foam concrete. The amount of cement are replaced by iron tailings at 0\%(a), 10\%(b), 30\%(c) and 50\%(d) of the foam concrete. 


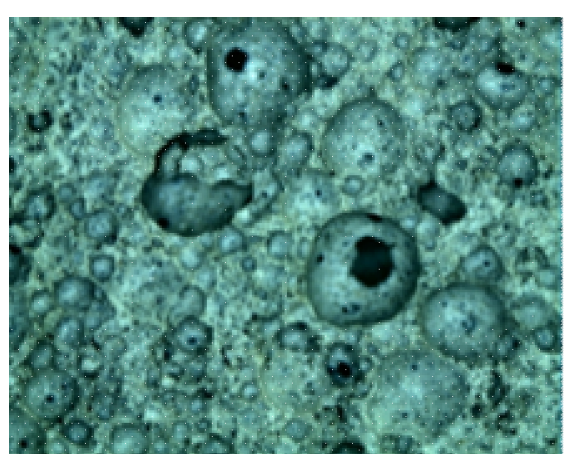

(a)

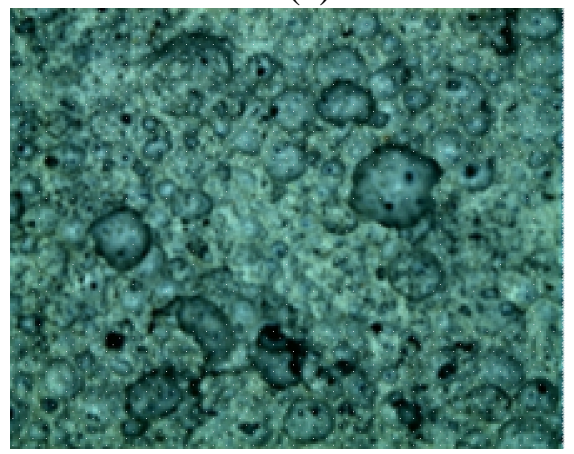

(c)

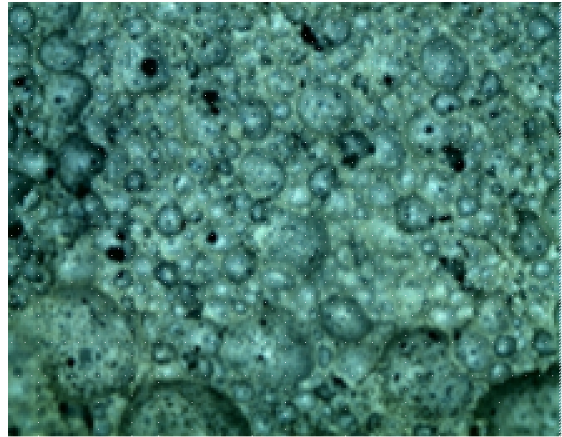

(b)

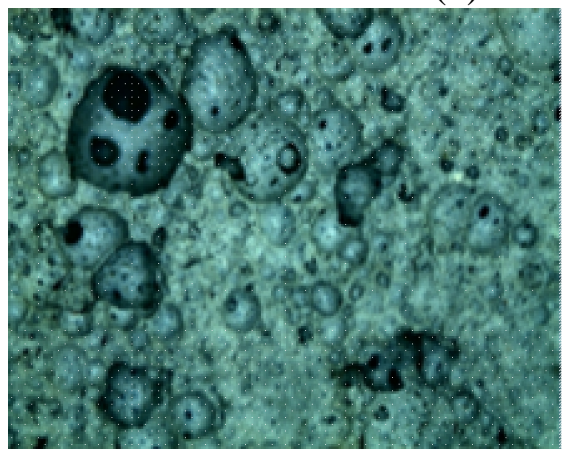

(d)

Fig. 5 When diluted multiples of the foaming agent is 50 times, the part images of foam concrete. The amount of cement are replaced by iron tailings at 0\%(a), 10\%(b), 30\%(c) and 50\%(d) of the foam concrete.

From Fig. 3, Fig. 4, Fig. 5 and their strength of the foam concrete conclusion can be obtained: when the amount of cement are replaced by iron tailings at 30\%, the internal porosity's distribution of foam concrete is uniform, the size of air hole are similar, due to other distribution of porosity is uneven and size of porosity is differ, the strength of concrete is low.

\section{Conclusion}

1. For making foam concrete, iron tailings is used to replace raw material. When diluted multiples of the foaming agent is 40 times, the strength of foam concrete is relatively high. At the same dilution ratio, the amount of cement are replaced by iron tailings at 30\%, the strength is relatively high.

2. The size of the air hole and its uniform distribution in the foam concrete will cause great influence to the strength.

3. Iron tailings can replace part of cement to make foam concrete, but the amount of iron tailings should not be too big otherwise affect the strength of foam concrete.

\section{Acknowledgements}

This work was financially supported by the Hebei Province Science and Technology Plan Project (16273706D).

\section{References}

[1]Jiexi Zhang, Bin Zhao and Bin Fang: The comprehensive utilization's research and actual discharge situation of iron tailings in China[J].Renewable resources and recycling economy, 9:29-32(2015)

[2]Shuhui Zhang, Xiangxin Xue and Zaifeng Jin: The present resources and comprehensive utilization of iron tailings in China [J].Journal of materials and metallurgy, 3(4):241-245(2004)

[3]Jin Min: The present research and application of foam concrete [J].Shanxi Architecture in China, 41(25):131-132(2015) 